\title{
Filigrane
}

Écoutes psychothérapiques

\section{Décès de Madame Nathalie Zalzman}

\section{Le comité de rédaction}

Volume 18, numéro 1, printemps 2009

Le corps. Sur le divan. Dans le fauteuil I

URI : https://id.erudit.org/iderudit/037714ar

DOI : https://doi.org/10.7202/037714ar

Aller au sommaire du numéro

Éditeur(s)

Revue Santé mentale au Québec

ISSN

1192-1412 (imprimé)

1911-4656 (numérique)

Découvrir la revue

Citer ce document

Le comité de rédaction (2009). Décès de Madame Nathalie Zalzman. Filigrane, 18(1), 3-3. https://doi.org/10.7202/037714ar d'utilisation que vous pouvez consulter en ligne.

https://apropos.erudit.org/fr/usagers/politique-dutilisation/ 


\section{Décès de Madame Nathalie Zalzman}

C'est avec regret que Filigrane a appris le décès de Madame Nathalie Zaltzman, membre de son comité scientifique, survenu à Paris le 11 février dernier. Madame Zaltzman était dévouée à la revue à laquelle elle a adressé plusieurs auteurs. Nous regretterons son départ.

Le comité de rédaction 